\title{
An investigation into the role of mothers in the care of hospitalized children as perceived by mothers and nurses in pediatric units of BPKIHS, Dharan, Nepal
}

\author{
U Yadav, BK Karn, S Shah, RN Chaudhary \\ Department of Child Health Nursing College of Nursing, BPKIHS, Dharan, Nepal
}

\begin{abstract}
Background: Over the last three decades the annual number of deaths among children less than 5 years of age has decreased by almost one third. However, this reduction has not been evenly distributed throughout the world Objective: The aim of the present study was to identify the role perception of mothers and nurses in the care of hospitalized children. Method: Comparative survey design was adopted for the study. A simple random sampling technique for mothers and purposive sampling for the nurses were used in selecting the subjects. The sample comprised of 50 mothers and 50 nurses. The data was collected by using interview schedule for mothers and semi-structured questionnaire for the nurses. The data obtained was analyzed using the descriptive and inferential statistics. Result: The study results showed that, $84 \%$ of mothers strongly agreed and $56 \%$ of nurses strongly agreed, with the role of mothers in the care of hospitalized children. Regarding comparison of the role of mothers as perceived by mothers and nurses, were found positively significant. As regards to relationship between the perceptions of mothers on her role with the selected background factors, revealed that there was no significant relationship. Conclusion: Mother's role in the care of hospitalized children is vital, as all expectations of satisfaction, trust and security of the child are vested in her. Mothers being a primary care provider of child has limited role in hospital but still can contribute in recovery of children.
\end{abstract}

Keywords: Child care, mother, nurses, perception

\section{Introduction}

Over the last three decades the annual number of deaths among children less than 5 years of age has decreased by almost one third.

\footnotetext{
Address for correspondence

Mr. Upendra Yadav

Additional Professor

Department of Child Health Nursing

College of Nursing, BPKIHS, Dharan

Email: upendrayadav2010@yahoo.com
}

However, this reduction has not been evenly distributed throughout the world. Every year more than 10 million children die in developing countries before they reach their fifth birthday. Seven in 10 of these deaths are due to acute respiratory infections (mostly Pneumonia), 
diarrhoea, measles, malaria, or malnutrition and often to a combination of these illnesses. Thus it is well understood that children of developing countries frequently get hospitalized.

Children having being fully or various level of dependency on mother before hospitalization need maternal support during hospitalization as well. The results study conducted Beraldi Salgado D 2014 highlighted the key role of nurses in promoting mother-child bonding despite political structures in maternity and pediatric centers. Unfortunately role of mother in caring child during hospitalization is not well defined.

The main aim of the study is to identify the role perception of mothers and nurses in the care of hospitalized children.

\section{Methods}

It is hospital based comparative survey study of patient admitted in pediatric wards of BPKIHS. A 50 nurses and mothers were taken for the study. A purposive sampling for the nurses and random sampling for the mothers were used to select the study subjects. A semistructured questionnaire for the nurses and an interview schedule for the mothers were used for the data collection. The collected data was entered in MS Excel. The obtained data was analyzed by using statistical package for the social sciences (SPSS) software package. Frequency percentage and Chi-square test was used for the study.

Content validity of the tools: To ensure content validity of the tools used in the present study, tools were given to 14 experts (2 Doctors \& 12 Nurse Educators), in the fields of Pediatric, Medical as well as Nursing. Percentage of agreement for the interview schedule and questionnaire were 100 percent. However, certain suggestions of experts were incorporated into the tools and modified accordingly. Tools were found valid for the study. English version of the tool was translated into Nepali by language expert and back from Nepali to English to counter check the translation.

\section{Results}

Description of sample characteristics of mothers. 
Table 1: Frequency and percentage distribution of mothers by their sample characteristics $(n=50)$

\begin{tabular}{|c|c|c|c|}
\hline S.N. & Characteristics & Frequency & Percentage (\%) \\
\hline 1 & $\begin{array}{l}\text { Age of mother } \\
\qquad \begin{array}{rl}1.1 & 21-30 \text { years } \\
1.2 & 31-40 \text { years } \\
1.3 & >41 \text { years }\end{array}\end{array}$ & $\begin{array}{c}14 \\
29 \\
7\end{array}$ & $\begin{array}{l}28 \\
58 \\
14\end{array}$ \\
\hline 2 & $\begin{array}{l}\text { Occupation of mother } \\
\begin{array}{l}2.1 \text { House wife } \\
2.2 \text { Business } \\
2.3 \text { Professional }\end{array}\end{array}$ & $\begin{array}{l}41 \\
5 \\
4\end{array}$ & $\begin{array}{c}82 \\
10 \\
8\end{array}$ \\
\hline 3 & $\begin{array}{l}\text { Education of mother } \\
\begin{array}{l}3.1 \text { Illiterate } \\
3.2 \text { Up to } 10^{\text {th }} \text { class } \\
\text { 3.3 Higher Secondary }\end{array}\end{array}$ & $\begin{array}{c}7 \\
31 \\
12\end{array}$ & $\begin{array}{l}14 \\
62 \\
24\end{array}$ \\
\hline 4 & $\begin{array}{l}\text { Family income in rupees } \\
\qquad \begin{array}{l}4.1<5000 \\
4.2>5000\end{array}\end{array}$ & $\begin{array}{c}9 \\
41\end{array}$ & $\begin{array}{l}18 \\
82\end{array}$ \\
\hline 5 & $\begin{array}{l}\text { Previous experience of hospitalization } \\
\qquad \begin{array}{l}5.1 \text { Yes } \\
5.2 \text { No }\end{array}\end{array}$ & $\begin{array}{l}15 \\
35\end{array}$ & $\begin{array}{l}30 \\
70\end{array}$ \\
\hline 6 & $\begin{array}{l}\text { Age of the hospitalized child } \\
\qquad \begin{array}{ll}6.1 & 1-3 \text { years } \\
6.2 & 3-5 \text { years }\end{array}\end{array}$ & $\begin{array}{l}40 \\
10\end{array}$ & $\begin{array}{l}80 \\
20\end{array}$ \\
\hline
\end{tabular}

Description of sample characteristics of nursing personnel 
Table 2: Frequency and percentage distribution of nursing personnel by their sample characteristics $(n=50)$

\begin{tabular}{|c|c|c|c|c|}
\hline S.N. & & Characteristics & Frequency & Percentage (\%) \\
\hline \multirow[t]{4}{*}{1} & Age & & & \\
\hline & 1.1 & $21-30$ years & 22 & 44 \\
\hline & 1.2 & $31-40$ years & 23 & 46 \\
\hline & 1.3 & 41 and above & 5 & 10 \\
\hline \multirow[t]{3}{*}{2} & Marital st & & & \\
\hline & 2.1 & Married & 28 & 56 \\
\hline & 2.2 & Unmarried & 17 & 34 \\
\hline \multirow[t]{4}{*}{3} & General e & ation & & \\
\hline & 3.1 & Up to $10^{\text {th }}$ class & 18 & 36 \\
\hline & 3.2 & Senior secondary $(10+2)$ & 24 & 48 \\
\hline & 3.3 & Bachelor Degree & 8 & 16 \\
\hline \multirow[t]{5}{*}{4} & Professio & education & & \\
\hline & 4.1 & General Nursing \& Midwifery & 25 & 50 \\
\hline & 4.2 & Diploma in Nursing Education & 10 & 20 \\
\hline & & \& Administration & & \\
\hline & 4.3 & B.Sc. Nursing & 15 & 30 \\
\hline \multirow[t]{3}{*}{5} & Duration & xperience & & \\
\hline & 5.1 & 1-10Years & 22 & 44 \\
\hline & 5.2 & $>10$ years & 28 & 56 \\
\hline \multirow[t]{3}{*}{6} & Attended & rt term course in "Pediatric care" & & \\
\hline & 6.1 & Yes & 33 & 66 \\
\hline & 6.2 & No & 17 & 34 \\
\hline
\end{tabular}

Table 3: Frequency and percentage distribution of perception scores of mothers regarding her role in the care of hospitalized children $(n=50)$

\begin{tabular}{|l|c|c|c|}
\hline Perception criteria & Class interval of scores & Frequency & Percentage \\
\hline Disagree & $40-60$ & 0 & 0 \\
\hline Agree & $61-100$ & 8 & 16 \\
\hline Strongly Agree & $101-120$ & 42 & 84 \\
\hline Total & & $\mathbf{5 0}$ & $\mathbf{1 0 0}$ \\
\hline
\end{tabular}


Table 4: Frequency and percentage distribution of perception scores of nurses regarding Mothers role in the care of hospitalized children $(n=50)$

\begin{tabular}{|l|c|c|c|}
\hline Perception criteria & Class interval of scores & Frequency & Percentage \\
\hline Disagree & $40-60$ & 0 & 0 \\
\hline Agree & $61-100$ & 22 & 44 \\
\hline Strongly agree & $101-120$ & 28 & 56 \\
\hline Total & & $\mathbf{5 0}$ & $\mathbf{1 0 0}$ \\
\hline
\end{tabular}

Table 5: distribution of mean scores of mothers and nurses area wise in the care of hospitalized children $(n=50+50)$

\begin{tabular}{|l|l|c|c|}
\hline \multirow{2}{*}{ S.N. } & \multicolumn{1}{|c|}{ Areas of child care } & \multicolumn{2}{c|}{ Mean scores } \\
\cline { 3 - 4 } & & Mothers & Nurses \\
\hline 1 & Willingness & 2.79 & 2.58 \\
\hline 2 & Nutrition & 2.75 & 2.50 \\
\hline 3 & Hygiene & 2.44 & 2.60 \\
\hline 4 & Toilet & 2.87 & 2.72 \\
\hline 5 & Emotion & 2.66 & 2.36 \\
\hline 6 & Rest \& activity & 2.61 & 2.61 \\
\hline 7 & Medication & 2.13 & 2.39 \\
\hline 8 & Observation & 2.75 & 2.74 \\
\hline 9 & General & 1.74 & 1.37 \\
\hline
\end{tabular}

Table 6: Chi- square value showing the relationship between the perceptions of mothers on her role with the selected background factors $(n=50)$

\begin{tabular}{|l|c|c|c|c|}
\hline Variables & Df & Tabulated value & Calculated chi value & Significant level \\
\hline Age & 2 & 5.99 & 0.390 & Not significant \\
\hline Education & 3 & 7.81 & 0.470 & Not significant \\
\hline $\begin{array}{l}\text { Prev. experience } \\
\text { of hospital }\end{array}$ & 1 & 3.84 & 0.611 & Not significant \\
\hline
\end{tabular}

Not significant $p=>0.05$ 


\section{Discussion}

\section{Major findings \& discussion of the study}

Findings related to perception scores of Mothers regarding her role in the care of hospitalized children revealed that $84 \%$ strongly agreed, and $16 \%$ agreed where as no one disagreed with their roles in the care of hospitalized children. The finding is supported by the finding of the study of Lee $R L$ et.al. (2013) which revealed that Chinese mothers' desire for participation in caring for their hospitalized child. Joshi reveled that only $51.35 \%$ of the parents had high level of satisfaction with the paediatric nursing care and most of the subjects were moderately satisfied with the paediatric nursing care.

The study conducted by $P$. Vasli and $M$. Salsali, et.al. (2014) on "Parents' participation in taking care of hospitalized children: A concept analysis with hybrid model "showed The clear role of parents in taking care of a hospitalized child is one of the important components of parents' participation in care. The difference between patients' and nurses' perceptions about the behaviors, which are considered as cares, causes conflicts between nurses and parents, lowers the quality of care, and increases dissatisfaction in both sides. Parents should be clearly active in decisionmaking process concerning their childcare, allocation of the person who takes care of their child, or the level of their own participation. Meanwhile, nurses should determine their clear expectations for the activities they like the parents to participate in. Similar kind of finding was observed in this study.

The finding of the study conducted by $F$. Asamoah, L. A. Sarfo et al, (2013) on the role of mothers in the care of children under five years on admission revealed that, mothers performed several roles for their sick children less than five years on admission. While, they enjoyed performing some of the roles, they did not enjoy performing others. Finding of the study is congruent with this study.

Again, the findings support that of Lee RL; Lau VW et.al. (2013) on an interpretive phenomenological study of Chinese mothers' experiences of constant vigilance in caring for a hospitalized sick child. The findings highlight Chinese mothers' desire for participation in caring for their hospitalized child, their unexpressed needs for communication, and concern about being uncared by the busy health professionals, which affect their care for the child's health outcomes.

Finding related to perceptions of nurses on the role of mothers of hospitalized children showed $56 \%$ strongly agreed, $44 \%$ of nurses agreed with the role of Mothers in the care of hospitalized children where as no one disagreed, with the role of mothers in the care of hospitalized children.

The comparisons of the role of mothers as perceived by mothers and by nurses were found positively significant. It shows that perception scores of mother and nurses in the 
care of hospitalized children are interrelated with each other.

In the investigation of the obtained components, the first important and notable element of this concept was open and interactive communication between two sides. This open communication absolutely can help concurrent usage of parents' and nurses' knowledge and their mutual cooperation.

Finding related to relationship between the perceptions of mothers on her role with the selected factors such as; age, and previous experience in the hospital, was not found to be statistically significant at 0.05 level of significance. It indicates that there is no significant relationship between the selected background factors and the perceptions of mothers on her role.

The study conducted by Whaley and Wong et.al. 1989 indicated that, many of the least educated mothers are shy and in order to avoid embarrassment, they tend to leave every aspect of the care of their hospitalized children, including the assessment of pain, to the nurses. From the findings, it is observed that, the ability of mothers to perform more roles in the care of their hospitalized children was dependent on their educational background.

But in this study no significant association was found with the educational background of mothers may be because of small number of sample and in developing country like Nepal where mothers seldom get chance to take care of their children in hospital.

\section{Conclusion}

Mother's role in the care of hospitalized children is vital, as all expectations of satisfaction, trust and security of the child are vested in her. Mothers being a primary care provider of child has limited role in hospital but still can contribute in recovery of children.

\section{Reference}

1. Abades Porcel M, Bibliographic study of bonding: caring for the mother-child attachment, Rev Enferm, 2014;37(1):1825

2. Enferm Clin. 2011; 21(6):338-43. Epub 2011 Sep 7.

3. Lai Wah Lam, Anne M. Chang, Jean Morrissey, July 2006, Parents' experiences of participation in the care of hospitalized children: A qualitative study, International Journal of Nursing Studies, 43(5), 535-545.

4. Espezel HJ1, Canam CJ, Parent-nurse interactions: care of hospitalized children, J Adv Nurs. 2003; 44(1):34-41.

5. Shields L, King SJ. Qualitative analysis of the care of children in hospital in four countries Parts 1, J Pediatr Nurs. 2001; 16(2):137-45.

6. Sister Roy Collista, "Role Cues for the mother of the hospitalized child; A.N.A. Clinical sessions, American nurses Association, Dallas 1968.195. 
7. Lee RL; Lau VW, An interpretive phenomenological study of Chinese mothers' experiences of constant vigilance in caring for a hospitalized sick child $_{2}$ J Adv Nurs 2013;69(8):1808-18 (ISSN: 1365-2648)

8. Mahaffy Perry R., "The effects of hospitalisation on children admitted for tonsillectomy and adenoidectomy", Nursing Research.

9. N.B. Mathur \& et al, National Rural Health Mission and Reduction of Neonatal and Infant Mortality Rate,
Journal of National Neonatology Form of India, Neonatal Nursing, 2005; 19(3):196197.

10. World Health Organization Statistical Information (WHOSIS), 2005

11. Benz Gladys S. Pediatric nursing. Saint Louis; C.V. Mosbey co.1964;66.

12. Blake Florence $G$, The child His parents and the nurses. Philadelphia; j.b. lippin cott.co. 1954.

13. Bingham, Walter. V.d. and Moore Bruce V. How to interview. New York; harper and brothers. 1959. 